Original Scientific Article

\title{
APPLICABILITY OF A SPECTROPHOTOMETRIC METHOD FOR ASSESSMENT OF OXIDATIVE STRESS IN POULTRY
}

\author{
Petra Regenhard ${ }^{1}$, Dimitar Nakov ${ }^{2}$, Helga Sauerwein ${ }^{1}$ \\ ${ }^{1}$ Institute of Animal Science, Physiology and Hygiene Group, \\ University of Bonn, Katzenburgweg 7-9, D-53115 Bonn, Germany \\ ${ }^{2}$ University Ss. Cyril and Methodius in Skopje, Faculty of Agricultural Sciences and Food, \\ Institute for Animal Biotechnology, Department for Animal Health and Welfare \\ Blvd. Aleksandar Makedonski, 1000 Skopje, Republic of Macedonia
}

Received 22 July 2013; Received in revised form 9 October 2013; Accepted 16 October 2013

\begin{abstract}
Oxidative stress is discussed as being related to health, welfare, and also to product quality. Recently, a spectrophotometric method based on the Fenton reaction (reactive oxygen metabolites, ROM) has been proposed to characterize pro-oxidative stressors in body fluids by determining early products of oxidation from proteins, lipids and nucleic acids. The applicability of this method for blood samples from various bird species was tested. The validity of the method for mammalian domestic animals was demonstrated by linearity yielded with increasing amounts of serum. In contrast, serum obtained from chicken yielded ROM concentrations below the limit of detection when serum volumes comparable to mammalian samples were used. Applying higher amounts of serum was not increasing the optical density readings in a linear way. To assess whether the lack of sensitivity and linearity is a problem limited to chicken or poultry in general, we tested sera from laying hens, turkey, duck, goose, pheasant, pigeon, and guinea fowl. For most of the species tested, the method could not be validly applied. There is no reason to assume that oxidative stress in birds may not exist, therefore we conclude that bird specific matrix effects hinder the valid application of the ROMs test in poultry.
\end{abstract}

Key words: oxidative stress; dROM test; poultry

\section{INTRODUCTION}

Oxidative stress has been defined as a loss of counterbalance between free radical or reactive oxygen species production and the antioxidant systems. Oxidative processes represent the main causes for meat quality deterioration. In addition, oxidative stress is increasingly discussed as being related to health (for review see 1,2 ) and has been proposed as a welfare parameter (3). There are basically three different methodological approaches to characterize oxidative stress: 1) Measuring the anti-oxidative capacity (either by evaluating

Corresponding author: Prof. H. Sauerwein, $\mathrm{PhD}$

E-mail address: sauerwein@uni-bonn.de

Present address: Institute of Animal Science, Physiology and Hygiene Unit, University of Bonn, Katzenburgweg 7-9, D-53115 Bonn, Germany tel: +49 228732804 / fax: +49228737938

Copyright: (C) 2014 Sauerwein H. This is an open-access article published under the terms of the Creative Commons Attribution License which permits unrestricted use, distribution, and reproduction in any medium, provided the original author and source are credited.

Competing Interests: The authors have declared that no competing interests exist.

Available Online First: 15 November 2013

http://dx.doi.org/10.14432/j.macvetrev.2013.10.002 individual components with anti-oxidative properties, e.g. tocopherol or glutathione peroxidase, or by assessing these components in a summative mode, i.e. as total anti-oxidative capacity. 2) Quantifying the oxidative damage in organic molecules; hereby monitoring lipid peroxidation via measuring thiobarbituric acid reactive substances (TBARS) is probably the most commonly applied test system in poultry science $(4,5,6)$. 3) Indirect assessment of free radicals via quantification of early products of oxidation such as hydroperoxides. The latter approach has become available only recently and is based on the concept that the amount of organic hydroperoxides is related to the free radicals from which they are formed $(7,8)$. The test takes advantage of the capacity of hydroperoxides to generate free radicals in the presence of transition metals (e.g. Fe) which act as catalyzers. When free radicals react with a chromogenic substance, they develop a colored complex that can be measured photometrically. Reference values have been established in humans 
and relationships with various diseases have been documented so far $(9,10,11)$. The test, called dROMs test (detection of reactive oxygen metabolites) has already successfully been applied for livestock animals and a number of data is now available for non-human mammals (3, 12, 13). We aimed to establish this test in our laboratory and to evaluate its relationship with other parameters indicative for oxidative stress in chicken. The test turned out to work well with porcine, equine, and bovine samples, but not with chicken sera. We therefore compared sera from other poultry species and herein report the limitations we observed for the application of the dROMs assay in poultry.

\section{MATERIALS AND METHODS}

\section{Animals, Sample Collection, and Preparation}

Blood was collected from laying hens, broilers, from turkey, duck, goose, pheasant, pigeon, and guinea fowl via puncture of the Vena basilica. In addition, blood was collected during slaughter from geese and broilers. Measurements were done in whole blood or in serum. For comparative purposes, blood serum from dairy cows and horses was used. For the preparation of serum, blood was allowed to clot at $4{ }^{\circ} \mathrm{C}$ and was then centrifuged at $4{ }^{\circ} \mathrm{C}$ and $3,000 \times \mathrm{g}$. Serum was then removed and stored at $-80^{\circ} \mathrm{C}$ until assayed.

Development and Application of a Laboratory Protocol for the Detection of Reactive Oxygen Metabolites

A spectrophotometric method, originally presented by Alberti et al. (8) was applied, in which N,N-diethyl-para-phenylendiamine (DEPPD) is used as chromogen. The alkoxy and peroxy radicals formed in the degradation of hydroperoxides brought about by transition metals in acidic conditions covert DEPPD to its corresponding radical cation DEPPD $^{+}$with can then be quantified at 505 or $549 \mathrm{~nm}$. The concentration of the colored dye is directly proportional to the concentration of hydroperoxides. The test can be performed according to either a kinetic or an end-point analysis. We herein used the end point analysis similar to the protocol of Trotti et al. (14). $\mathrm{H}_{2} \mathrm{O}_{2}$ was used as standard and for the generation of a standard curve, a range of $0.4 \mu \mathrm{g} / \mathrm{ml}(0.013 \mathrm{mM})$ to $4 \mu \mathrm{g} / \mathrm{ml}(0.13 \mathrm{mM}) \mathrm{H}_{2} \mathrm{O}_{2}$ was incubated in $10 \mu \mathrm{L}$ volumes together with $10 \mu \mathrm{L}$ chromogen $\left(3.7 \times 10^{-1} \mathrm{M}\right.$ N,N-Diethyl-1,4phenylendiammomiumsulphate, Merck, Darmstadt, Germany), $10 \mu \mathrm{L}$ of $6 \mathrm{mM} \mathrm{FeSO}_{4}$ (Merck) and $0.97 \mathrm{~mL}$ acetate buffer $(0.01 \mathrm{M}, \mathrm{pH} 5.0)$ for $2 \mathrm{~h}$ at $37{ }^{\circ} \mathrm{C}$. After cooling for $10 \mathrm{~min}$ in an ice-bath, the absorption was determined with a spectrophotometer (Hitachi U-2000, Mannheim, Germany) at $505 \mathrm{~nm}$. Water was used instead of $\mathrm{H}_{2} \mathrm{O}_{2}$ as blank and the absorbance value of the blank was subtracted from those of the standard and the samples. The assay variation was assessed by repeated measurements ( $n=17$ and $n=14$, respectively) of two bovine serum samples. The linearity of the assay was evaluated with bovine and equine blood serum and with serum obtained from various bird species in a range of 5 to $200 \mu \mathrm{L}$. The values obtained were then calculated from the standard curves using linear regression and were finally expressed as $\mu \mathrm{g} / \mathrm{ml} \mathrm{H}_{2} \mathrm{O}_{2}$ equivalents.

\section{RESULTS}

The standard curves demonstrated a linear relationship between absorption measurements and the amount of $\mathrm{H}_{2} \mathrm{O}_{2}$ (Fig. 1).

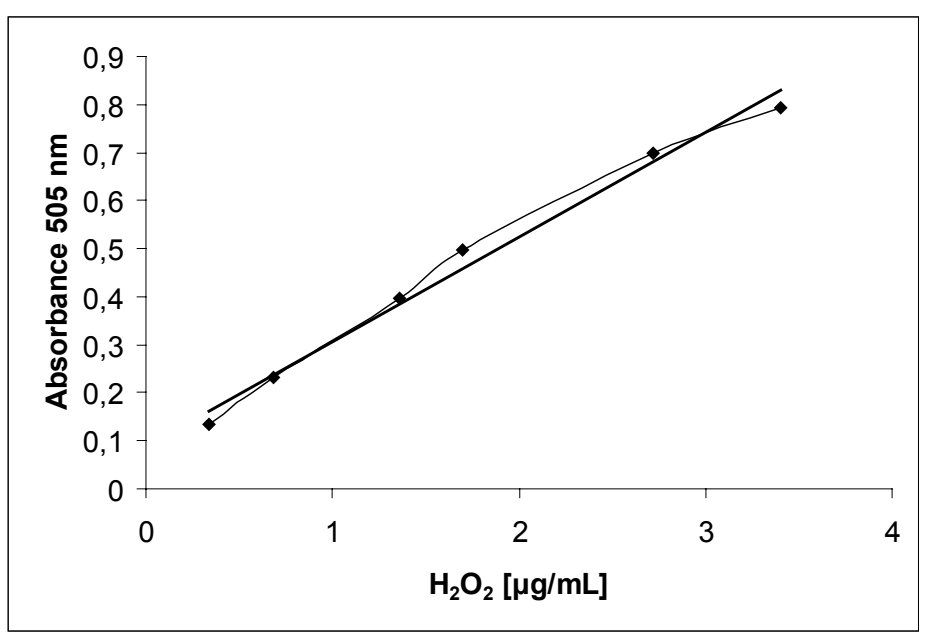

Figure 1. Representative standard curve using different concentrations of hydrogen peroxide $\left(\mathrm{H}_{2} \mathrm{O}_{2}\right)$. The regression equation was $\mathrm{y}=0088+67,333 \mathrm{x}$ with $\mathrm{r}=0.99$. 
Using bovine samples, the linearity of the assay was established in a range between 5 to $40 \mu \mathrm{L}$ serum (Fig. 2).

The coefficients of variation obtained from the two bovine control samples were $2.76 \%$ and $2.88 \%$, respectively. The limit of detection was defined as the $\mathrm{H}_{2} \mathrm{O}_{2}$ concentration that yielded readings presence of $12.5 \mu \mathrm{M}$ uric acid [final concentration, i.e. corresponding to $1.25 \mathrm{mM}$ in undiluted serum thus slightly exceeding reference values reported for bird species that reportedly range from 0.2 to $0.8 \mathrm{mM}(14,15)]$. However, the OD readings of the standard curve were not impaired by addition of uric acid to the assay system (data not shown).

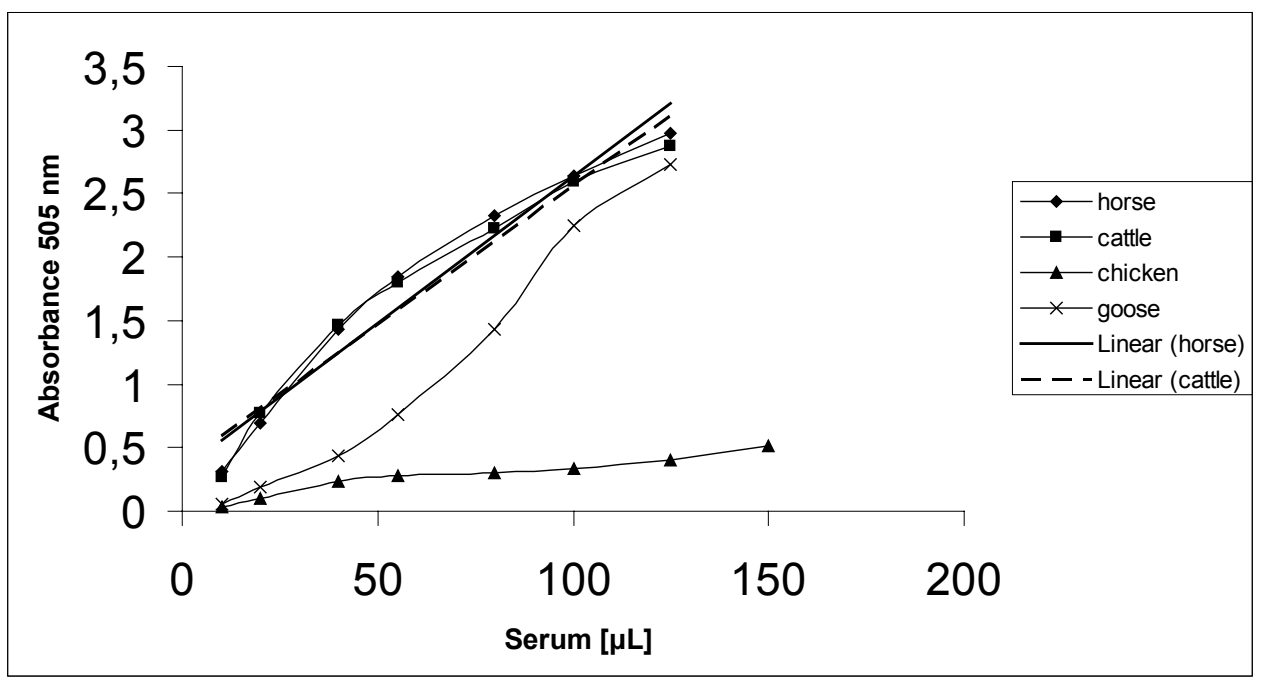

Figure 2. Evaluation of assay linearity using different volumes of serum obtained from the following species: Cattle, Horse, Chicken (broiler), Goose (Demonstration of regression lines is limited to the samples for which linearity could be established)

significantly different $(\mathrm{p}<0.05)$ from the blank value measured by using $\mathrm{H}_{2} \mathrm{O}$ and corresponds to the lowest standard concentration of $0.4 \mu \mathrm{g} / \mathrm{mL} \mathrm{H}_{2} \mathrm{O}_{2}$. Comparing the $\mathrm{H}_{2} \mathrm{O}_{2}$ equivalents measured in $10 \mathrm{uL}$ serum volumes from bird species, markedly lower values than in bovine serum were observed. In most cases the values were below the limit of detection. Using different amounts of the different bird sera, linearity could not be confirmed. From the various bird species assayed, only goose samples yielded a short linear range, all other bird sera could not be validly assayed (data not shown). Evaluation of assay linearity using different volumes of serum obtained from cattle, horse, goose, and chicken is demonstrated in Fig. 2. To substantiate our initial observation, that the dROMs test can not be used for chicken serum, we also tested the commercially available kit (Callegari, Parma, Italy) according to the manufactures instruction both with whole blood and with serum, and obtained the same result of lacking linearity. In consideration of serum constituents that differ between birds and mammals, we also tested the effect of assaying the standard curves in

\section{DISCUSSION}

We previously used the dROM test successfully with bovine, porcine, equine, and canine whole blood and serum $(16,17,18,19,20)$ but noted that the test cannot be validly used with chicken serum. The same observation was confirmed when using the commercially available version of the dROMS kit and we thus conclude that this test cannot be used for chicken whole blood or serum. In the only report about the use of the dROM test in chicken (21), we could find in the literature, no data about the validity of the assay for this matrix were provided, and the values reported were out of the linearity range of d-ROMs as assessed in a comparison of different methods about oxidative stress tests (22).

Our results indicate that matrix components being exclusively present in blood serum of most of the poultry species tested, severely interfere with the dROMs test and thus prohibit the valid application of this test principle for these species. One of the serum components for which a marked difference between bird and mammalian serum is well-known, 
is uric acid. In birds, the metabolism of proteins and amino acids results in the production of uric acid, and not as in mammals, of urea (23). Recent studies revealed that uric acid has been proposed to be the dominant antioxidant in birds $(24,25)$. Decreasing uric acid production in birds by approximately $33 \%$ causes an increase in oxidative stress, as evidenced by increased accumulation of markers of reactive species mediated tissue damage (26). Uric acid is an antioxidant because it can inactivate an oxidant by an electron transfer before the oxidant can react with the targeted biological molecule (27). This enhanced ability to scavenge hydroxyl radicals may contribute to the reduction in markers of reactive species-mediated tissue injury observed in broiler chickens with elevated plasma uric acid concentrations (15). Stinefelt et al. (24), using Electron spin resonance spin trapping technique, adding uric acid to the reaction mixure to final concentration ranged from 0.0 to $3.5 \mathrm{mM}$ reported effective reducing of spin adduct signal intensity over $50 \%$ with $3.5 \mathrm{mM}$ uric acid. Other authors reported that uric acid may have a stimulatory effect on lipid peroxidation at higher concentrations (28). However, there was no effect of adding the uric acid to the assay system. As already expected from the results with goose samples, uric acid can thus be excluded as the interfering component. Methods to specifically circumvent this problem can presently not be proposed: any approach to fractionate or extract serum will inevitable alter the oxidative status and will thus adulterate the results.

\section{ACKNOWLEDGEMENT}

We thank Ms. Barbara Heitkönig for excellent technical assistance. The scholarship of the German Academic Exchange Service (DAAD) awarded to Mr. Dimitar Nakov is gratefully acknowledged.

\section{REFERENCES}

1. Knight, J.A. (2000). Review: Free Radicals, Antioxidants, and the Immune System. Ann Clin Lab Sci; 30 (2): 145-158.

2. Abuja, P.M., Albertini, R. (2001). Methods for monitoring oxidative stress, lipid peroxidation and oxidation resistance of lipoproteins. Clin Chim Acta 306: 1-17.

3. Brambilla, G., Civitareale, C., Ballerini, A., et al. (2002). Response to oxidative stress as a welfare
4. Botsoglou, N.A., Fletouris, D.J., Papageorgiou, G.E., Vassilopoulus, V.N., Mantis, A.J., Trakatellis, A.G. (1994). Rapid, sensitive and specific thiobarbituric acid method for measuring lipid peroxidation in animal tissue, food and feedstuff samples. J of Agric Food Chem 42: 1931-1937.

5. Jo, C., Ahn, D.U. (1998). Fluorometric analysis of 2-thiobarbituric acid reactive substances in turkey. Poult Sci 77(3): 475-480.

6. Young, J.F., Stagsted, J., Jensen, S.K., Karlsson, A.H., Henckel, P. (2003). Ascorbic acid, alpha-tocopherol, and oregano supplements reduce stress-induced deterioration of chicken meat quality . Poult Sci 82(8): 1343-1361.

7. Cesarone, M.R., Belcaro, G., Caratelli, M., et al. (1999). A simple test to monitor oxidative stress. Int Angiol 18(2): 127-130.

8. Alberti, A., Bolognini, L., Macciantelli, D. (2000). The radical cation of N,N-Dienthylparaphenylendiamine: a possible indicator of oxidation stress in biological samples. Research Chemical Intermedicine 26: 253-267.

9. Carlucci, F., Tabucchi, A., Biagioli, B., et al. (2002). Cardiac surgery: myocardial energy balance, antioxidant status and endothelial function after ischemia-reperfusion. Biomed Pharmacother 56: 483-491.

10. Campise, M., Bamonti, F., Novembrino, C., et al. (2003). Oxidative stress in kidney transplant patients. Transplantation 76: 1474-1478.

11. Christou,K.,Markoulis, N.,Moulas,A.N.,Pastaka,C., Gourgoulianis, K.I. (2003). Reactive oxygen metabolites (ROMs) as an index of oxidative stress in obstructive sleep apnea patients. Sleep Breath 7: 105-110.

12. Brambilla, G., Fiori, M., Archetti, L.I. (2001). Evaluation of the oxidative stress in growing pigs by microplate assays. J Vet Med A Physiol Pathol Clin Med. 48(1): 33-38.

13. Ballerini, A., Civitareale, C., Fiori, M., Regini, M., Betti, M., Brambilla, G. (2003). Traceability of inbred and crossbred Cinta Senese pigs by evaluating the oxidative stress. J Vet Med A Physiol Pathol Clin Med 50: 113-116.

14. Shapiro, F., Mahagna, M., Nir, I. (1997). Stunting effect in broilers; effect of glucose or maltose supplementation on digestive organs, intestinal disaccharidases, and some blood metabolites. Poult Sci 1997; 75:369-380.

15. Simoyi, M., Van Dyke, K., Klandorf, H. (2002). Manipulation of plasma uric acid broiler chicks and its effect on leukocyte oxidative activity. Am J Physiol;282: 791-796.

16. Trotti, R., Carratelli, M., Barbieri, M., et al. (2001). Oxidative stress and a thrombophilic condition in alcoholics without severe liver disease. Haematologica 86: 85-91. 
17. Rekitt, M., Sauerwein, H., Andresen, U. (2002). Orientierende Untersuchungen zum oxidativen Stress bei Reitpferden. Tierärztl. Umsch 57: 471481.

18. Rekitt, M., Staub, M., Andresen, U., Sauerwein, H. (2003). Orientierende Untersuchungen zum oxidativen Stress bei Hunden. Tierärztl Umsch 58: 70-78.

19. Andresen, U., Rekitt, M., Sauerwein, H. (2003). Orientierende Untersuchungen zum oxidativen Stress bei Milchkühen und zur Wirksamkeit peripartaler intramuskulärer Gaben von Vitamin E/ Selen. Tierärztl Umsch 58: 467-472.

20. Sauerwein, H., Schmitz, S., Hiss, S. (2005). The acute phase protein haptoglobin and its relation to oxidative status in piglets undergoing weaninginduced stress. Redox Report 10(6): 295-302.

21. Celi, P., Selle, P.H., Cowieson, A.J. (2013). The effects of dietary supplementation with different organic selenium sources on oxidative stress in

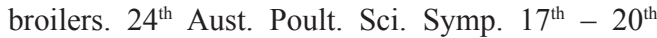
February 2013, 76-79.

22. Palmieri, B., Sblendorio, V. (2007). Oxidative stress tests: overview on reliability and use, Part II. European Review for Medical and Pharmacological Sciences, 11:383-399
23. Beitz, D.C. (2004) Protein and Amino Acid Metabolism. In: Reece WO, ed. Dukes Physiology of Domestic Animals. Cornell University Press, Ithaca, USA, 535-552.

24. Stinefelt, B., Leonard, S.S., Blemings, K.P., Shi, X., Klandorf, H. (2005). Free radical scavenging, DNA protection, and inhibition of lipid peroxidation mediated by uric acid. Annals of Clinical and Laboratory Science, vol. 35, no. 1, 37-45.

25. Carro,M.D.,Falkenstein,E.,Radke,W.J., Klandorf,H. (2010). Effects of allopurinol on uric acid concentrations, xanthine oxidoreductase activity and oxidative stress in broiler chickens. Comparative Biochemistry and Physiology, Part C, 151: 12-17.

26. Klandorf H, Rathore D, Iqbal M, Shi X, Simoyi M, Van Dyke K. (2002). Acceleration of tissue aging in chickens caused by oxidative stress using allopurinol and detected by cellular humoral chemiluminescence. In: Luminescence Biotechnology (Van Dyke K, Van Dyke C, Woodfork K, Eds), CRC Press, New York,; pp 393-407.

27. Simic M, Jovanovic S. (1989). Antioxidation mechanisms of uric acid. J Amer Chem Soc; 111:5778-5782.

28. Santos C, Anjos E, Augusto O. (1999). Uric acid oxid-ation by peroxynitrite: multiple reactions, free radical formation, and amplification of lipid oxidation. Arch Biochem Biophys; 372:285-294. 